\title{
Gonad development in farmed male and female South African abalone, Haliotis midae, fed artificial and natural diets under a range of husbandry conditions
}

\section{Esther Meusel}

Vetmeduni Vienna: Veterinarmedizinische Universitat Wien

Simon Menanteau-Ledouble ( $\square$ simonml@bio.aau.dk)

Aalborg University https://orcid.org/0000-0002-3435-9287

Matthew Naylor

HIK Abalone Farm

Horst Kaiser

Rhodes University

Mansour El-Matbouli

Vetmeduni Vienna: Veterinarmedizinische Universitat Wien

\section{Research}

Keywords: abalone, Haliotis midae, artificial diet, soya, phytoestrogens, husbandry, gonad bulk index, sexual maturation rate

Posted Date: July 27th, 2021

DOI: https://doi.org/10.21203/rs.3.rs-735927/v1

License: (c) (i) This work is licensed under a Creative Commons Attribution 4.0 International License.

Read Full License

Version of Record: A version of this preprint was published at Aquaculture International on February 21st, 2022. See the published version at https://doi.org/10.1007/s10499-022-00850-6. 


\section{Abstract \\ Background}

Growth rate is considered one of the most important factors in the farming of Haliotis midae and somatic growth rates decline after abalone reach sexual maturity. Artificial diets are suspected to accelerate maturation, in particular when soya meal is used as a protein source, because of this plant's high concentration of phytoestrogens.

\section{Results}

We fed two artificial diets and a natural diet, kelp. The first artificial diet had fishmeal as its main source of protein while the other, Abfeed ${ }^{\circledR} \mathrm{S} 34$, replaced some of the fish proteins with soya meal. The effect of diet on the gonad development of 27-month-old farmed Haliotis midae, raised at two stocking densities, was analysed. For each gonad sample the development phase was determined based on both histological criteria and the gonad bulk index (GBIn). The hypothesized link between dietary protein source and gonad development could not be established by either morphological criteria or GBIn. Similarly, stocking density did not have a significant effect on GBIn-values. GBIn values were significantly correlated to the results from the histological analyses in males and females.

\section{Conclusions}

The results from this study suggest that artificial diets including those using soya meal are a valid alternative in the feeding of abalone. Moreover, it provides a data base for future research on factors influencing gonad development in this species.

\section{Simple Summary}

The objective of this study was to describe gonadal development in female and male South African abalone, H. midae, a commercially valuable species of Haliotids. The animals were fed two pelleted diets with and without soya meal and kelp, which represents their natural diet. In addition, they were kept at two stocking densities and a range of water flow rates. The use of artificial diets is a common practice in the farming of $\mathrm{H}$. midae and these diets can include soya meal as a partial substitute for fish meal. Stocking density, flow rate and soya meal inclusion did not have a significant effect on the sexual maturity of both male and female $\mathrm{H}$. midae. A combination of histological assessments and measurements of gonad tissue area made it possible to distinguish reproductive development in both sexes between months of the spawning season.

\section{Background}


According to the United Nation's Food and Agriculture Organization, South Africa is since 2004 the largest abalone producer outside Asia. Concurrently, the economic value of abalone mariculture for coastal communities has increased [1-3]. Abalone farming requires a high capital investment and relies on formulated diets to improve productivity by increasing abalone growth $[1,2,4,5]$ and food conversion ratio $[2,3,6]$. These diets are good alternatives to the natural diet of abalone, i.e., kelp and seaweeds, and they have been used in combination with macroalgal diets [7]. Among the advantages of these pelletized diets is the fact that they can be modified to match the life stages and dietary needs of the farmed abalone [8] as well as the fact that they are more practical than a natural kelp or seaweed diet as they are available throughout the year $[2,8]$. Some farms combine artificial diets and kelp in the production of the South African abalone, Haliotis midae [2], and other haliotids [9], but artificial diets are mostly used in the grow-out period of $H$. midae [10]. Typical main ingredients in artificial diets are fish meal, defatted soybean meal and casein as protein sources $[8,11,12]$. A combination of fish meal and soybean meal can result in faster abalone growth than diets with fishmeal as the only main protein source $[10,13]$. For example, Abfeed ${ }^{\text {tm }}$ S34 ${ }^{\circledR}$ (Marifeed Pty Ltd), the diet used in the present study, is a commercial feed for post-weaning of abalone containing fishmeal and soybean meal as the main sources of protein.

Animals fed Abfeed ${ }^{\text {TM }}$ grew faster than animals fed kelp up to an age of two and a half years, after which growth was reduced [3]. The onset of growth reduction corresponded to the age at which $H$. midae can reach sexual maturity under farm conditions [14], which may cause the channelling of metabolic energy into gonad development [15]. This hypothesis is supported by differences in sexual maturation between wild and farmed $H$. midae $[14,16-18]$. In captivity, $50 \%$ of male and female abalone reached sexual maturity at 18 months and two years, respectively [14]. Wild abalone, however, attain sexual maturity at an age of approximately 7 years [18]. Early sexual maturity has an impact on the farming of $H$. midae, as this species takes approximately four years from hatching to a marketable weight of 80 g.abalone ${ }^{-1}$ [3]. Abalone are broadcast spawners with a high gonadal mass index in both males and females of up to 75 $\mathrm{mm}^{3} \cdot \mathrm{g}^{-1}$ soft tissue [10]. Therefore, uncontrolled sexual development and spawning may complicate growth forecasting, which is required for successful farm management, product quality and marketing of the animals.

The ingredients in artificial diets may play an additional role. H. midae raised on formulated feeds with fishmeal as the only protein source devoted more energy to gonad development than abalone fed diets that included both fishmeal and soybean meal [10]. Soybean meal is rich in phytoestrogens, which are suspected to act as endocrine disruptors in $H$. midae [10] and other animal species [19-21]. However, Wu et al. (2019) [10] tested soybean meal in $H$. midae diets and could not confirm that the flavonoids in soybean meal are responsible for the hypothesized effect on gonad development. In other species, phytoestrogens have been linked to precocious genital development, decreased testosterone levels, altered activity levels, decreased prostate weight, decreased sperm quality, temporary or permanent infertility, abnormal lactation in mammals, an increased incidence of dystocia and feminization [20, 2224]. In fish, soybean-based diets caused shifting of the sex-ratio towards females, decreased testosterone 
levels, reduced fertility through an effect on the number of eggs spawned and sperm quality, inadequate gametogenesis and a reduction of fertilization and hatch rate [25-28].

There is a paucity of published information on the effect of soybean meal on abalone gonad development in both males and females when compared to natural diets. For example, in feeding studies that were designed to analyse gonad development of $H$. midae, kelp was not included as a test diet [10, 13, 29]. Capinpin \& Corre (1996) [30] suggested that growth was fastest in $H$. asinina fed artificial diets as compared to red algae, Gracilariopsis heteroclada, until the abalone reached a size at which energy was channelled into gonad development. The authors hypothesized that this was due to the relatively high protein and energy content of these diets, but gonad mass index (GBI) was not determined and no histological evidence was provided to support this hypothesis.

An additional factor that may influence gonad development in $H$. midae is stocking density and water flow rate. Abalone are broadcast spawners and can be triggered to release eggs and sperm by the presence of gametes in the water column. Spontaneous spawning events have been recorded in $\mathrm{H}$. asinina [31]. Counihan et al. [32] have suggested that high stocking densities in tanks may influence the frequency of spawning events in $H$. asinina due to the fact that abalone are closer together, which may result in males releasing gametes and associated sex pheromones. Thus, the number of abalone in a tank may influence gonad development or the frequency of spawning events. Furthermore, during spawning season and under favourable environmental farm conditions $H$. midae broodstock can reproduce approximately every six weeks [14], which suggests a fast recruitment of oocytes. Broodstock abalone are kept in a controlled environment at low population densities, which is different from the conditions in the grow-out tanks, with variable and generally high numbers of abalone and consequently fast water flow rates. The effect of stocking density on abalone reproductive development in a grow-out system remains to be tested.

The aim of this study was to use histological examination to compare the effect of a partial substitution of the fishmeal in the artificial diet with soybean meal on gonad development of both male and female $H$. midae. In addition, a treatment, in which abalone were fed kelp, the natural diet, was included. Abalone stocking intensity and water flow rate to the culture tanks were used as additional independent variables.

\section{Methods}

\section{Animals and culture conditions}

Twenty-seven months-old $H$. midae (30-40 $\mathrm{g}_{\text {abalone }}{ }^{-1}, 55-60 \mathrm{~mm}$ length) were randomly collected at the grading station of an on-shore abalone farm in Hermanus, South Africa in early December 2010 where they had been fed a natural diet of kelp. Based on information available from farms in the Western Cape region of South Africa, it was estimated that the animals would be immature and that only $60 \%$ of animals within this size range had started to develop gonadal tissue. As they were still too immature to be sexed, the ratio of male to female abalone was not determined at the time of collection. 
The abalone were transferred to eighteen 300-L tanks with oyster mesh baskets and a horizontal floating top feeding plate on which the artificial food was placed. Abalone are nocturnal feeders and come to the feeding plate at night. Each tank had its own water inflow and outflow with filtered water $(100 \mu \mathrm{m})$ from the farm's header tank.

The effect of stocking intensity on growth and gonad development was tested by farming the animals at two densities, which were expressed as the percentage of available basket surface area that could be covered by the abalone. To estimate the required biomass of abalone, regression models developed by farm management to predict foot surface area as a function of biomass were used. In the low stocking density (LI), there was a biomass of $8 \mathrm{~kg}^{\text {basket }}{ }^{-1}$ with animals covering $17.5 \%$ of the surface area of the basket and flow rates of $9 \mathrm{~L} \mathrm{~h}^{-1} \mathrm{~kg}^{-1}$ to $20 \mathrm{~L} \mathrm{~h}^{-1} \mathrm{~kg}^{-1}$. In the high stocking density $(\mathrm{HI})$ treatment, the density of animals was $11 \mathrm{~kg}^{\text {basket }}{ }^{-1}$, so that $24 \%$ of the available basket surface area was covered by the animals. In this treatment, seawater flow rate ranged from $13 \mathrm{~L} \mathrm{~h}^{-1} \mathrm{~kg}^{-1}$ to $29 \mathrm{~L} \mathrm{~h}^{-1} \mathrm{~kg}^{-1}$.

The abalone were fed either a commercial diet with fishmeal (FM) as the main protein source or the standard Abfeed ${ }^{\circledR}$ S34 diet (Marifeed; Pty Ltd) with a combination of fishmeal and soybean meal. The diets were isonitrogenous (33.2\% protein) and isocaloric (15.6 $\mathrm{MJ} \mathrm{kg}^{-1}$ ) with an average lipid level of $3.6 \%$. The daily feeding rate was approximately $0.5 \%$ of body mass, which is an established feeding rate for the average body mass used in this experiment [8]. Daily rations were calculated at the beginning of the trial, based on the weight of the animals in a basket, and adjusted every two weeks according to the growth of the animals.

Both $\mathrm{LI}$ and $\mathrm{HI}$ treatments were randomly assigned to baskets in eight tanks; four tanks in each group received the FM diet and the other four received Abfeed ${ }^{\circledR}$ S34. Experimental units were randomly allocated to the combinations of artificial diets and stocking density.

Two baskets received locally harvested kelp (Ecklonia maxima), which was fed in excess. These animals were stocked at the low population density with a high flow rate $\left(20 \mathrm{~L}^{\mathrm{kg}} \mathrm{kg}^{-1} \cdot \mathrm{h}^{-1}\right)$.

\section{Sampling and processing of gonadal tissue}

Because the sex of immature abalone cannot easily be differentiated, three individuals, a female, a male and an immature individual that was not yet displaying clear sexual characteristics, were sampled from each tank at each sampling time, i.e., immediately before the start of the feeding experiment and at the end of each of the following two months. In all but one case, histological examination correctly identified the sex of individuals even when it was not evident macroscopically. From January, all animals had matured so that their sex was clearly identifiable and animals of undefined sex were no longer collected. In total 126 animals $(\mathrm{N}=126)$ were used for the study.

Following collection, the animals were left overnight for purging in separate bags labelled with the tank number. The gonads were removed the following day after the animals had been shucked according to farm protocol. The entire conical organ was placed in Davidson's solution for fixation. The gonad tissue 
was cut and stained at the Division of Anatomy and Histology of Stellenbosch University (Tygerberg, South Africa). Dehydration of the fixed samples was achieved in serial dilutions of ethanol (70-100\% $\mathrm{v} / \mathrm{v}$ ) for 180 minutes each. The specimens were cleared with xylene for 150 minutes and embedded in paraffin wax for 120 minutes at $60^{\circ} \mathrm{C}$. Specimen blocks were processed in sections of $5 \mu \mathrm{m}$ thickness and incubated at $60^{\circ} \mathrm{C}$ for 60 minutes in an autoclave. Afterwards, sections were rehydrated in a serial dilution of ethanol $(100-70 \% \mathrm{v} / \mathrm{v})$, stained with haematoxylin-eosin, dehydrated in a serial dilution of ethanol $(70-100 \% \mathrm{v} / \mathrm{v})$ and cleared with xylene. Sections were mounted onto microscope slides with di-n-butyl phthalate in xylene mounting medium (Fluka).

For every specimen, three cross-sections, all originating from the mid-point between the base and the tip of the conical organ, were stained and mounted.

An image capturing device, ScanScope ${ }^{\circledR} \mathrm{CS}$ (Aperio), was used to take micrographs of the slides. These digital micrographs were analysed using the viewing software ImageScope Version 11.1 (Aperio). Measurements were taken using this software and the histology of the samples was interpreted.

\section{Slide analysis and histological examination}

\subsubsection{Determination of abalone sex and developmental phase}

In one case, in which the sex of the abalone was not determinable through macroscopic examination, histology was used. Histology was also performed to evaluate the developmental phase of the animals. It has been established that the development of the ovary occurs at the same pace throughout the length of the organ [33]. Therefore, for each individual conical organ, a single cross-section, from midway between the base and the tip was analysed to evaluate the developmental phase of each gonad.

Classification of the germ cells of female and male gonads and the description of the gamete cell developmental stage were based on published criteria for Haliotids [14, 17, 34, 35]. Stages of oogenesis were determined following the criteria proposed by Visser-Roux [14], however, the size of the nucleus and nucleolus did not always fall within the reference range or could not be measured. Therefore, nucleus and nucleolus size were not used as criteria for gamete classification. Each gonad was assigned a developmental phase (immature, proliferative, premature, mature, spawning, spent) according to this classification.

The testicular developmental phases were primarily assigned according to cell stages and their relative abundance. The gonad surface area covered by spermatids and spermatozoa was given a value of "< $25 \%$ ", " $25-75 \%$ " or "> 75\%".

The ovaries were evaluated using cell counts. Numbers of oogenetic stages along a horizontal and a vertical midline as well as in randomly selected high power fields (HPF) were counted. Frequencies were 
determined and the presence of yolk throughout the gonad was staged into high, moderate and low levels.

The approach used to determine cell frequencies and classify the gonadal development phase varied between male and female abalone. In females, the percentages of each stage present along a vertical and horizontal midline and ten randomly selected HPFs were established. Cell stages were discriminated by measuring cell size and by comparing their morphology using the descriptions by Visser-Roux [14]. While transverse sections along the length of the ovaries were similar to each other [33], the various cell cohorts within these sections often reached maturity at different times. In these samples, the phase of each inter-trabecular compartment was determined. The developmental phase dominating the gonad surface area was then established and the sample was classified based on this developmental phase.

\section{Evaluation of the gonad index}

Newman's gonad bulk index [36] was calculated for each sample. The surface area of the conical organ (total area of section) and the hepatopancreas (GI area) were measured using Imagescope Version 11.1 software. For each individual the gonad surface area (area of gonad section) was calculated by subtracting the $\mathrm{GI}$ area from the total area of the section. The GBIn was then calculated using the following equation: GBIn = (area of gonad section / total area of section) $\times 100$. The GBIn values were compared to the developmental phase based on the morphological criteria.

\section{Statistical analysis}

Statistical analyses were performed using Microsoft EXCEL 2010 and IBM SPSS v20: The logtransformed values of the GBIn were normally distributed (Kolmogorov-Smirnov-test). The effect of the independent variables, month, dietary protein source and stocking density, on the continuous dependent variables was analysed by comparing the GBIn of the animals that had received either of the diets using a general linear model (GLM, ANOVA). Each factor was then analysed independently using one-way analysis of variance (ANOVA). Post-hoc tests were performed using the Bonferroni alpha error correction.

GBIn values were compared to reproductive stages in both females and males using the Spearman Rank $\mathrm{R}$ correlation procedure.

\section{Results}

Eighteen abalone of macroscopically undefined sex were collected in December, which is in mid-summer in the southern hemisphere. Of these animals only one could not be sexed using histology while the others comprised of 14 females and three males.

Sections from two individuals were excluded from developmental phase analyses due to their low quality. Furthermore, these analyses excluded the group belonging to the stage "spawning". The animals in this group appeared to have released gametes when handled during the process involved in purging. The two individuals in the "spawning" group made up $1.6 \%$ of the total number of animals. There were no 
changes in the significance levels of statistical tests when including or excluding the "spawning" group data.

In addition, 10 samples were excluded because of artefacts on the slides.

In the ovarian sections a staggered development of cohorts within the gonad was apparent in most samples. Premature compartments (Fig. 1A, C, and D) were frequently positioned next to mature or proliferative compartments. Areas of the gonad sporadically showed signs of necrosis as described by Najmudeen [34]. The developmental phase that covered the largest fraction of the gonad area was assigned to that individual based on the criteria described in materials and methods (Fig. 1B and G).

In the testes, primary spermatocytes were counted as a single stage while secondary spermatocytes occurred in negligible numbers (Fig. 1E). This observation is in agreement with that of Singhakaew et al. [35]. Numbers of late stages, i.e., spermatids and spermatozoa, could not be counted, since they were too numerous (Fig. 1F and $\mathrm{H}$ ), too small and often overlapped. They were therefore described as the mean percentage of total gonad area as estimated in ten randomly selected high power fields (HPF) per gonad.

\section{GBIn-values}

There was a significant difference in mean GBIn-values between all means of the three development phases in females $(p<0.0001)$. In males mean GBIn-values differed between the lowest percentage abundance $(<25 \%)$ and the other two means, $25 \%-75 \%$, and $>75 \%$, respectively $(p<0.0001)$, while these two means were similar with each other (Fig. 2, A, B).

The sampling month, i.e., December, January and February, had a significant effect on the developmental phase distribution of females $(p<0.001)$, which occurred between December and January $(p<0.0001)$ as well as between December and February $(p<0.0001)$, but not between January and February. Similarly, in males, the month had a significant effect on GBIn-values with the mean value for December being different from the means for January and February $(p<0.01)$ (Fig. 2, C and D).

There was no significant interaction $(p>0.05)$ between month and diet on mean GBIn for females and males with similar average values for the three diets within each sex (Fig. 2, E, F).

In both males and females there was no significant effect of flow rate and farming intensity on the gonad index $(p>0.05)$. In average, the GBIn-values were significantly higher in males than in females $(p=0.028)$.

There was no significant effect of diet and stocking density on the developmental phase of females ( $p=$ $0.651, p=0.52$, respectively) and males ( $p=0.44, p=0.14$, respectively).

GBIn values were significantly correlated to the histologically defined maturity stages in females $(R=$ $0.84, p<0.05)$ and males $(R=0.38, p<0.05)$.

\section{Developmental synchronicity}


Figure 3 compares the numbers and percentages of mature females and males with relative abundance values of spermatids and spermatozoa of $>75 \%$ for each diet. In abalone fed Abfeed S34, the ratio of mature males to females was 0.9:1, which was closer to 1:1 than for the other two diets.

\section{Discussion}

The applied method of quantifying reproductive development in female and male South African abalone, H. midae, made it possible to distinguish developmental stages for both sexes between months of high reproductive activity. Diet, stocking density and water flow rate to the tanks did not affect mean GBInvalues in either sex. The comparison of the total numbers of male and female abalone that had reached their respective highest maturity stage suggested that an approximately equal number of abalone of both sexes that were fed the Abfeed S34-diet had reached maturity, while this ratio was more variable in the other two diets. This approach of data analysis differed from other studies on the same species because we estimated gonadal development by comparing numbers and percentages of mature females and males between diets. As GBIn values were significantly correlated to maturity stages, the method used in the present study could be used in future experiments in which both GBIn-data and maturity stages will be reported.

Other studies have investigated the effect of diet on the growth of $H$. midae $[1,8,12,37-40]$ by comparing diets with soya meal inclusion with diets that only contained fishmeal as the protein source $[10,13,15,29]$. The natural macroalgal diet, kelp, was not included. While some research on abalone kept under these conditions only focused on female development [13, 29], Wu et al. [10,15] has previously reported on the combined effect of dietary composition and abalone sex on gonad development by comparing GBI-values that were expressed as the estimated effective gonad volume $\left(\mathrm{mm}^{3}\right)$ per $\mathrm{g}$ of shucked abalone mass. In addition, frequency distributions of developmental stages of gametes in both sexes were compared over a 180-day growth period [10]. Three abalone of each sex were collected every 45-days. In the present study, the frequencies of mature males and females could be compared using larger sample sizes. For comparisons of gonad maturity phases, we used gonad indices developed by Newman (1967) [36]. Gurney and Mundy (2004) [33] stated that GBIn as suggested by Newman (1967) correlated well with gonad histology and therefore constituted an adequate measure of fluctuations in the reproductive cycle. According to Sobhon et al. [41] gonad indices relate gonad area to constant parameters, such as the size of the conical organ, and do not take variation of hepatopancreas size into account, so that they cannot always provide a good estimate of the development of the gonads [41]. In the present study, GBIn was used as a measure of the developmental phase in combination with histological assessments. Using this method, differences in mean GBIn between months within the spawning season could be detected.

A potential limitation for GBIn analyses is the reliability with which the area of the conical organ and the hepatopancreas can be measured. For example, 11 samples for which these measurements could not be made were excluded, while the analysis of the remaining samples allowed for an assessment of developmental changes. 
An additional objective of this study was to investigate the effect of stocking density and flow rate on reproductive development in $\mathrm{H}$. midae, a broadcast spawner in which spatial closeness of abalone to each other and the release of pheromones may trigger spawning events. This species can spawn repeatedly within the reproductive season and spontaneous spawning events have been reported to occur once or twice per month [42]. It was therefore assumed that differences in development due to husbandry conditions could be detected within the time frame chosen for the present study. However, stocking density and water flow rate did not have an effect on GBIn values. Only two abalone had spent gonads, but this was likely caused by handling during purging. Therefore, spontaneous spawning events in $H$. midae could not be confirmed under the stocking densities and flow rates chosen for this experiment.

Future experiments may benefit from a longer duration as it may take more time for nutritional or environmental factors to have effects on reproductive development.

During the initial size-grading procedure, $40 \%$ of the animals had not shown macroscopically visible sexual characteristics. However, microscopic examination allowed for the identification of nascent gonadal tissue in several of the immature abalone and all but one sample could be assigned to a sex. A more sensitive method for sex determination may increase the chance of detecting individuals that have not reached maturity at the time of sampling. For example, it was proposed to assess sexual differentiation based on the measurement of the expression levels of the gene coding for the zona pellucida domain 4 (zp4) using real-time quantitative PCR in the disk abalone, Haliotis discus hannai [43]. This approach could be tested in future studies, especially at the earliest stages of reproductive development.

\section{Conclusions}

We investigated the effect of soy meal in the diet of abalone on gonadal maturation in H. midae. In the short term, the gonad development of abalone was not significantly influenced by farming conditions or the inclusion of soya meal as a source of protein. Under experimental conditions, any of the diets used in the present study could be fed for three months during summer without negative effects on gonad development or a loss of biomass as a result of spawning. However, because of the likely economic impact of precocious sexual development, more studies addressing this subject would be beneficial to. The results from this trial can contribute to a data base that can be used in future research.

\section{Abbreviations}

\section{ANOVA}

Analysis of variance

FM

Fishmeal diet

GBI

Gonad mass index 
GBIn

Gonad bulk index

GI

Gastrointestinal

GLM

General linear model

$\mathrm{HI}$

High stocking density

HPF

High power fields

LI

Low stocking density

PCR

Polymerase chain reaction

SPSS

Statistical Package for the Social Sciences

zp4

Zone pellucida domain 4

\section{Declarations}

Ethics approval and consent to participate

The study design was conducted with the ethical approval of all relevant bodies in Austria and South Africa.

Consent for publication

Not applicable.

Availability of data and materials

The datasets used and/or analysed during the current study are available from the corresponding author on reasonable request.

Competing interests

The authors declare that they have no competing interests.

\section{Funding}

This work was supported by the Joint Study scholarship program of the University of Veterinary Medicine of Vienna and Rhodes University, South Africa. The funders had no role in the design of the study; in the 
collection, analyses, or interpretation of data; in the writing of the manuscript, or in the decision to publish the results.

\section{Authors' contributions}

Conceptualization, design of the experiment and acquisition of funding MN, HK and MEM; Conduct of the experiments EM; Supervision of the experiments MN and HK; Data analysis EM and SML; Writingoriginal draft preparation, EM; writing-review and editing HK, MN, and SML. All authors have read and agreed to the published version of the manuscript.

\section{Acknowledgments}

The authors with to acknowledge the invaluable assistance they received from Dr. Alexander Tichy for the statistical analysis of the data.

\section{References}

1. Dlaza TS. Growth of juvenile abalone under aquaculture conditions. Dep. Biodivers. Conserv. Biol. [Cape Town. South Africa]: University of the Western Cape; 2006.

2. Makhande ED. Growth of the South African Abalone (Haliotis midae) on Three Diets, Under Commercial Conditions. South Africa: Nelson Mandela Metropolitan University; 2008.

3. Troell M, Robertson-Andersson D, Anderson RJ, Bolton JJ, Maneveldt G, Halling C, et al. Abalone farming in South Africa: An overview with perspectives on kelp resources, abalone feed, potential for on-farm seaweed production and socio-economic importance. Aquaculture. 2006;257:266-81. Available from: http://www.sciencedirect.com/science/article/pii/S0044848606001906.

4. Cho SH, Kim DS. Effects of Feed Type and Temperature on Growth of Juvenile Abalone, Haliotis discus hannai Ino. J World Aquac Soc. Blackwell Publishing Ltd; 2012;43:114-9. Available from: http://dx.doi.org/10.1111/j.1749-7345.2011.00517.x.

5. López-Acuna LM. Growth and the Energy Budget of Juveniles of the Abalone Haliotis tuberculata (L.). [Southampton]: University of Southampton; 1999.

6. Bautista-Teruel MN, Millamena OM, Fermin AC. Reproductive performance of hatchery-bred donkey's ear abalone, Haliotis asinina, Linne, fed natural and artificial diets. Aquac Res. Blackwell Science, Ltd; 2001;32:249-54. Available from: http://dx.doi.org/10.1046/j.1355-557x.2001.00022.x.

7. Kemp JOG, Britz PJ, Toledo Agüero PH. The effect of macroalgal, formulated and combination diets on growth, survival and feed utilisation in the red. abalone Haliotis rufescens. Aquaculture. Elsevier B.V.; 2015;448:306-14. Available from: http://dx.doi.org/10.1016/j.aquaculture.2015.06.016.

8. Sales J, Britz PJ. Research on abalone (Haliotis midae L.) cultivation in South Africa. Aquac Res. Blackwell Science Ltd; 2001;32:863-74. Available from: http://dx.doi.org/10.1046/j.13652109.2001.00629.x. 
9. Bansemer MS, Qin JG, Harris JO, Howarth GS, Stone DAJ. Nutritional requirements and use of macroalgae as ingredients in abalone feed. Rev Aquac. 2016;8:121-35. Available from: https://onlinelibrary.wiley.com/doi/10.1111/raq.12085.

10. Wu $\mathrm{Y}$, Kaiser $\mathrm{H}$, Jones CLW. A first study on the effect of dietary soya levels and crystalline isoflavones on growth, gonad development and gonad histology of farmed abalone, Haliotis midae. Aquac Int. 2019;27:167-93. Available from: http://link.springer.com/10.1007/s10499-018-0315-6.

11. Fleming AE, Van Barneveld RJ, Hone PW. The development of artificial diets for abalone: A review and future directions. Aquaculture. 1996;140:5-53. Available from: http://www.sciencedirect.com/science/article/pii/0044848695011846.

12. Shipton TA, Britz PJ. The effect of animal size on the ability of Haliotis midae L. to utilize selected dietary protein sources. Aquac Res. Blackwell Science Ltd; 2001;32:393-403. Available from: http://dx.doi.org/10.1046/j.1365-2109.2001.00572.x.

13. Riddin NA. Growth and gonad size in cultured South African abalone, Haliotis midae. MSc thesis, Rhodes Univ. Grahamstown, South Africa. Rhodes University; 2013.

14. Visser-Roux A. Reproduction of the South African abalone. In: Haliotis midae. South Africa: Stellenbosch University; 2011.

15. Wu Y. A holistic approach in understanding the effects of dietary protein sources on the growth and reproductive development of farmed abalone, Haliotis midae. Rhodes University; 2020.

16. Newman GG. Growth of the South African abalone Haliotis midae. Investl Rep Div Sea Fish Afr. 1968;64:1-24.

17. Wood AD, Buxton CD. Aspects of the biology of the abalone Haliotis midae (Linne, 1758) on the east coast of South Africa. 1. Feeding biology. South African J Mar Sci. Taylor \& Francis; 1996;17:61-8. Available from: http://dx.doi.org/10.2989/025776196784158590.

18. Tarr RJQ. Growth and movement of the South African abalone Haliotis midae: A reassessment. Mar Freshw Res. 1995;46:583-90. Available from: http://www.publish.csiro.au/paper/MF9950583.

19. Adams NR. Detection of the effects of phytoestrogens on sheep and cattle. J Anim Sci. 1995;73:1509-15. Available from: http://www.journalofanimalscience.org/content/73/5/1509.abstract.

20. Weber K, Setchell K, Stocco D, Lephart E. Dietary soy-phytoestrogens decrease testosterone levels and prostate weight without altering LH, prostate 5alpha-reductase or testicular steroidogenic acute regulatory peptide levels in adult male Sprague-Dawley rats. J Endocrinol. 2001;170:591-9. Available from: http://joe.endocrinology-journals.org/content/170/3/591.abstract.

21. Le Francois NR, Jobling M, Carter C, Blier PU. Finfish Aquaculture Diversification. Wallingford: CABI Publishing; 2010.

22. Cong L, Qin Z-F, Jing X-N, Yang L, Zhou J-M, Xu X-B. Xenopus laevis is a potential alternative model animal species to study reproductive toxicity of phytoestrogens. Aquat Toxicol. 2006;77:250-6. Available from: http://www.sciencedirect.com/science/article/pii/S0166445X06000142. 
23. Glover A, Assinder SJ. Acute exposure of adult male rats to dietary phytoestrogens reduces fecundity and alters epididymal steroid hormone receptor expression. J Endocrinol. 2006;189:565-73.

Available from: http://joe.endocrinology-journals.org/content/189/3/565.abstractN2 -

Phytoestrogens are plant-derived compounds with oestrogenic activity. They are common in both human and animal diets, particularly through soy-based foods. This study assessed whether ex.

24. Gupta RC. Veterinary Toxicology: Basic and Clinical Principles. 2nd ed. Oxford: Elsevier LTD; 2012.

25. Bagheri T, Imanpoor MR, Jafari V, Bennetau-Pelissero C. Reproductive impairment and endocrine disruption in goldfish by feeding diets containing soybean meal. Anim Reprod Sci. 2013;139:136-44. Available from: http://www.sciencedirect.com/science/article/pii/S0378432013000444.

26. El-Sayed A-FM, Abdel-Aziz E-SH, Abdel-Ghani HM. Effects of phytoestrogens on sex reversal of Nile tilapia (Oreochromis niloticus) larvae fed diets treated with 17a-Methyltestosterone. Aquaculture. 2012;360-361:58-63. Available from: http://www.sciencedirect.com/science/article/pii/S0044848612004115.

27. Pollack SJ, Ottinger MA, Sullivan CV, Woods LC. The Effects of the Soy Isoflavone Genistein on the Reproductive Development of Striped Bass. N Am J Aquac. Taylor \& Francis; 2003;65:226-34. Available from: http://www.tandfonline.com/doi/abs/10.1577/C02-041.

28. Tzchori I, Degani G, Elisha R, Eliyahu R, Hurvitz A, Vaya J, et al. The influence of phytoestrogens and oestradiol-17 $\beta$ on growth and sex determination in the European eel (Anguilla anguilla). Aquac Res. Blackwell Science Ltd; 2004;35:1213-9. Available from: http://dx.doi.org/10.1111/j.13652109.2004.01129.x.

29. Ayres DWP. Effect of diet and sex-sorting on growth and gonad development in farmed South African abalone, Haliotis midae. M.Sc. Thesis. Rhodes University; 2013.

30. Capinpin ECJ, Corre KG. Growth rate of the Philippine abalone, Haliotis asinina fed an artificial diet and macroalgae. Aquaculture. 1996;144:81-9. Available from: http://www.sciencedirect.com/science/article/pii/S0044848696013324.

31. Fermin AC, Gapasin RSJ, Teruel MB. Spontaneous Spawning, Fecundity and Spawning Periodicity in the Donkey's Ear Abalone Haliotis Asinina Linnaeus. In: Hylleberg A, editor. Proc 10th Int Congr Work Trop Mar Mollusc Program (TMMP), 20-30 Oct 1999, Hanoi Haiphong, Vietnam Phuket, Thail. Phuket: Phuket Marine Biological Center; 2000. pp. 195-201.

32. Counihan R, McNamara D, Souter D, Jebreen E, Preston N, Johnson C, et al. Pattern, synchrony and predictability of spawning of the tropical abalone Haliotis asinina from Heron Reef, Australia. Mar Ecol Prog Ser. 2001;213:193-202. Available from: http://www.intres.com/abstracts/meps/v213/p193-202/.

33. Gurney LJ, Mundy CN. Reproductive Biology: Identifying Spawning Cycles The Genus Haliotis. Tech Rep Ser Tasmanian Aquac Fish Institute; Hobart, Tasmania. 2004;23.

34. Najmudeen TM. Ultrastructural studies of oogenesis in the variable abalone Haliotis varia (Vetigastropoda: Haliotidae). Aquat Biol. 2008;2:143-51. Available from: http://www.intres.com/abstracts/ab/v2/n2/p143-151/. 
35. Singhakaew S, Seehabutr V, Kruatrachue M, Sretarugsa P, Romratanapun S. Ultrastructure of male germ cells in the testes of abalone, Haliotis ovina Gmelin. Molluscan Res. 2003;23:109-21. Available from: http://www.publish.csiro.au/paper/MR02016.

36. Newman GG. Reproduction of the Souh African abalone Haliotis midae. Investl RepDiv Sea Fish S Afr. 1967;64:1-24.

37. Britz PJ. The suitability of selected protein sources for inclusion in formulated diets for the South African abalone, Haliotis midae. Aquaculture. 1996;140:63-73. Available from: http://www.sciencedirect.com/science/article/pii/0044848695011978.

38. Britz PJ. Effect of dietary protein level on growth performance of South African abalone, Haliotis midae, fed fishmeal-based semi-purified diets. Aquaculture. 1996;140:55-61. Available from: http://www.sciencedirect.com/science/article/pii/0044848695011986.

39. Lopez L, Tyler PA, Viana MT. The effect of temperature and artificial diets on growth rates of juvenile Haliotis tuberculata (Linnaeus, 1758). J Shellfish Res. 1998;17:657-62.

40. Naidoo K, Maneveldt G, Ruck K, Bolton JJ. A Comparison of Various Seaweed-Based Diets and Formulated Feed on Growth Rate of Abalone in a Land-Based Aquaculture System. J Appl Phycol. Kluwer Academic Publishers; 2006;18:437-43. Available from: http://dx.doi.org/10.1007/s10811006-9045-7.

41. Sobhon P, Apisawetakan S, Chanpoo M, Wanichanon C, Linthong V, Thongkukiatkul A, et al. Classification of Germ Cells, Reproductive Cycle and Maturation of Gonads in Haliotis asinina Linnaeus. ScienceAsia. 1999;25:3-21.

42. Henry NR. Studies related to the artificial spawning and culture of the Abalone, Haliotis midaelinne, 1785. University of Cape Town; 1996. Available from: http://hdl.handle.net/11427/14354.

43. Choi M-J, Oh YD, Kim YR, Lim HK, Kim J-M. Use of a gene encoding zona pellucida 4 as a femalespecific marker for early stage sexual differentiation and size dimorphism in the pacific abalone Haliotis discus hannai. Anim Reprod Sci Elsevier BV. 2021;225:106687.

https://doi.org/10.1016/j.anireprosci.2021.106687.

\section{Figures}

\section{Figure 1}

Histological views of the gonads of Haliotis midae at various stages of maturation A: Immature gonad where $a=$ hepatopancreas; $b=$ gonial cells; $c=$ inner layer of capsule composed of collagenous fibres and smooth muscle cells and $d=$ outer layer of the capsule composed of a single layer of epithelial cells. $\mathrm{B}$ : Female gonads in the proliferative stage where $\mathrm{a}=$ hepatopancreas; arrow = oogonia and early-stage oocytes; arrowhead = trabeculae. C: Low magnification view of a female gonad in the premature stage. D: Detailed view of a female gonad in the premature stage where $a=$ hepatopancreas; $b=$ oocytes in the 
stage 6 of development; arrow = oogonia; arrowhead = trabeculae. E: Low magnification view of a male gonad in the premature stage. F: Detailed view of a male gonad in the premature stage where arrow = spermatogonia maturing into primary spermatocytes maturing as they get further from the trabeculae; arrowhead= spermatids and spermatozoa. G: Low magnification view of a mature female gonad. H: Low magnification view of a mature male gonad.
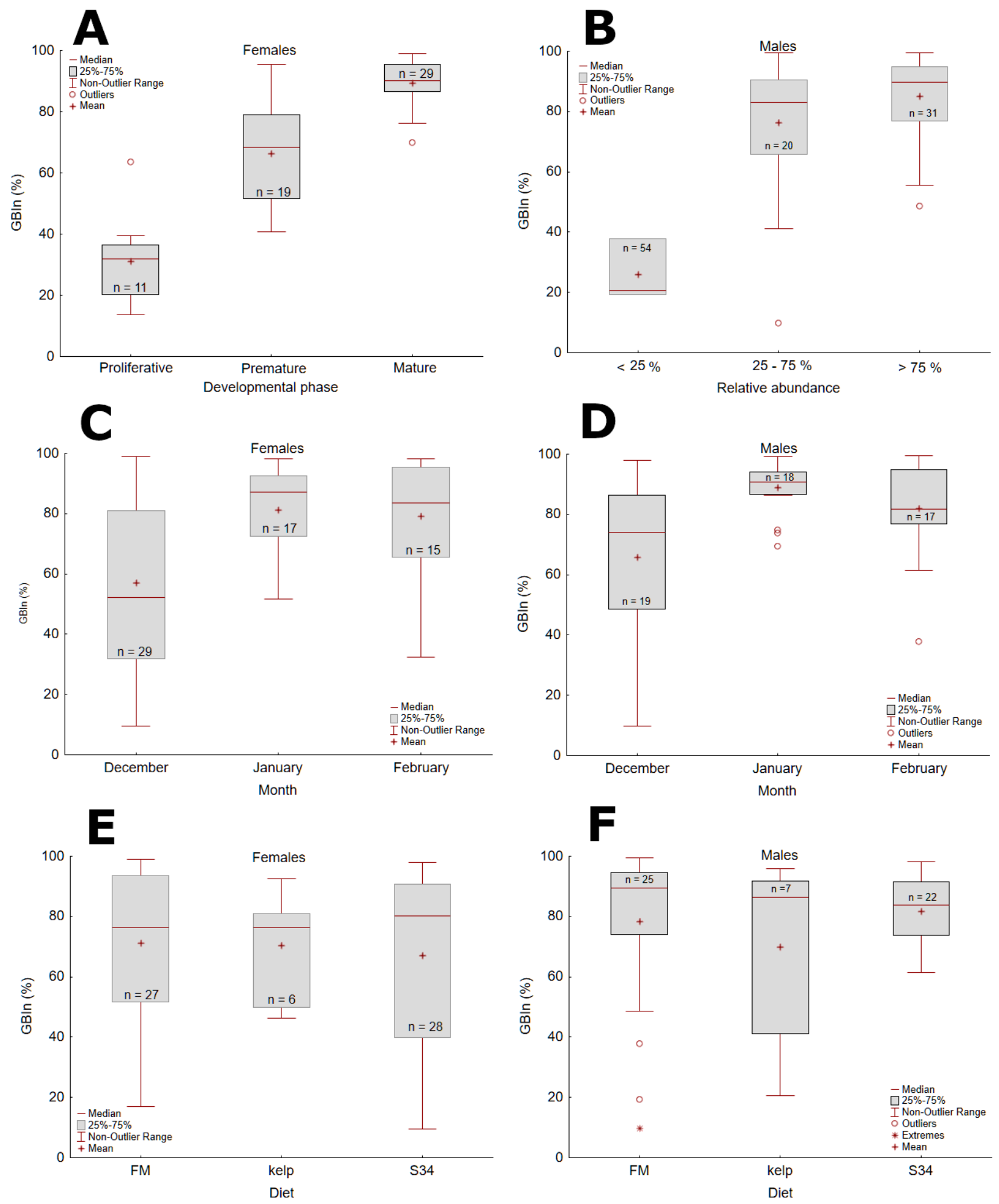

Figure 2 
Gonad Bulk Index (\%) statistics for female and male abalone. The data is divided based on the developmental phase $(A)$ in females and relative abundance of spermatids and spermatozoa in males $(B)$, the months of the experiment $(C, D)$ and the diets fed $(E, F)$.

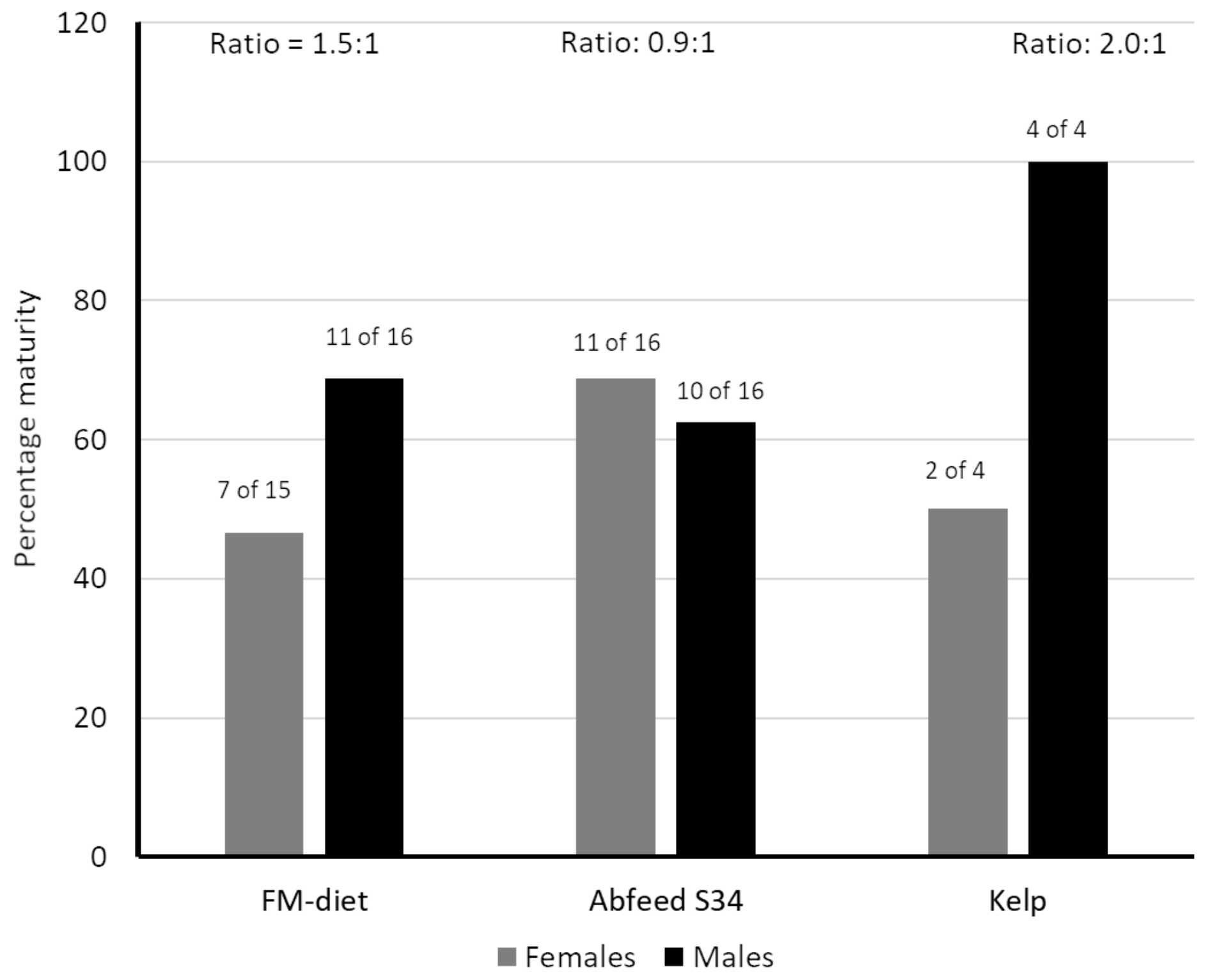

\section{Figure 3}

Numbers and percentages of mature females and males with relative abundance of spermatids $>75 \%$. The data is shown for each diet in January and February. The ratios of the numbers of males to females are shown on top of each bar. 